\title{
JAPANESE LITERATURE \\ IN ROMANIAN TRANSLATION: \\ THE CASE OF YUKIO MISHIMA
}

George T. SIPOS

West University of Timișoara

george.sipos@e-uvt.ro

\section{Japanese Literature in Romanian Translation: The Case of Yukio Mishi- ma}

DOI: 10.35923 /AUTFi1.59.09

The translation and reception of Japanese literature in Romania has followed the vicissitudes of the country's coming into modernity in the 19th century and slide into fascism and communism throughout the 20th century, as well as the subsequent ups and downs of the relationship with Japan. This research offers a brief overview of that sinuous path. It then focuses on the pre- and post-1990 reception of the works of Yukio Mishima (1925-1970, one of the iconic figures of Japan's postwar literature and exemplary for his continued trials and tribulations with modernity. By making use of scholarly and journalistic sources, the current incipient research provides several examples of the translation and reception of Mishima's works in Romania, as well as the extent to which his presence in this literary space has managed to permeate the psyche of Romanian scholars, literary critics and readers alike.

Keywords: Yukio Mishima, Japan, Romania, translation, Japanese literature, Modernity.

\section{Japanese Literature in Romanian: A Brief Overview}

While in most Western cultures, the translation and reception of Japanese literature fall within a bi-temporal paradigm with World War Two as the distinct divider, in Romania, there are three very clearly-defined periods: the 
prewar, ranging roughly from the beginning of modernity in Japan with the Meiji Restoration (and which coincides almost perfectly with the same process in the Romanian Principalities) to the end of World War Two ${ }^{1}$; the postwar, ranging from 1945 to 1989, and covering the country's Soviet occupation, communist regime and dictatorship; and, the post-1989, or the post-socialist period, with Romania's subsequent re-opening to the world and acceptance of cultural values largely forbidden especially in the last two decades of the dictatorial regime, under Romanian Communist Party general secretary and self-proclaimed president of the republic, Nicolae Ceauşescu (1918-1989).

The prewar relationships and reception of Japanese culture and spirituality in Romania constitute still a research desideratum and are outside the purpose of the current piece. Suffices to say that diplomatic relations were established between the two young modern countries and later allies in World War 2 in 1921, with the opening of Romania's legation in Tokyo (Japan 2019). It is then no surprise that around the 1920s we see the first significant publications about Japan, either original writings or translations, such as interwar intellectual and film maker Ioan Timuş (1890-1969)'s book Japonia: Viaţa şi obiceiurile (Japan: Life and Customs) (Timuş 1924), written following his travels and seven years of life (1917-1924) spent in Japan, or the 1929 translation by Constant Georgescu of Inazō Nitobe's Bushidō (Nitobe 1929), still republished in Romania to this day. In an excellent contribution to the history of Japan's reception in Romania, Marcel Mistrasca identified other volumes of various degrees of scientific rigor, as well as numerous travelogues (Mitrasca 2006). It was also Mitrasca who pointed out that there were very few translations from Japanese literature at least until the late 1930s, and those were all done via intermediary languages, such as French or English (Mitrasca 2006: 244). ${ }^{2}$

1 The author would like to thank the colleagues who so kindly and promptly helped with resources for this article: Associate Prof. Dr. Rodica Frențiu ("Babeș Bolyai” University), Associate Prof. Dr. Rodica Grigore (“Lucian Blaga” University), Laura Cocora, PhD Candidate (Cornell University), and Associate Prof. Dr. Iulia Waniek ("Dimitrie Cantemir" Christian University). A previous version of this article was published in Italian in Ciaparonni La Rocca, Teresa (ed.) 2020, Mishima monogatari: Un samurai delle arti, Turin, Edizioni Lindau, p. 205-214.

A brief visit to the Yokohama shiryōkan (Archives) some years ago did, however, revealed the possibility of pre-1868 contacts between the Kyūshū domains and the Romanian Principalities through the documented presence of a ship under "Romanian" flag in Japan's waters in the $1850 \mathrm{~s}$, a hypothesis that requires further research.

2 Mitrasca wrongly identified Chinese Canadian female writer Winnifred Eaton (1875- 
During the postwar years, Romania fell under Soviet influence and was occupied by the Red Army for the first years following the end of World War Two. Its political and social system and its modern nation state built in the 80 years prior to 1945 was dismantled, gun in hand, and Stalinism was imposed as of 1948 as the only accepted political doctrine. Following the Soviet politics of the time, very little cultural contact was allowed with the old Axis ally Japan, and, as such, it was not until the 1960s that major literary translations begin to be published - the period and literature of 1950s Romania, suffocated as it was under the imposed precepts of socialist realism, came to be known in Romanian literary history as the "obsedantul deceniu" (the obsessive decade). As expected, most of the works that make it to state-owned publishers in the 1960s are authored by Japanese proletarian or communist writers, whose works had already been vetted politically by being first translated into and published in Russian. This was the case of science fiction and mystery writer Hoshi Shin'ichi (1926-1997) and of Takakura Teru (1891-1986). However, for Romanian readers, the relative détente following Stalin's death did allow access to other writers such as Abe Kōbō (1924-1993), whose 1962 masterpiece, Suna no onna (The Woman in the Dunes), was translated into Romanian in 1968, probably from an English or Spanish translation, by Magdalena Levandovski-Popa, and published in an extremely popular collection of pocketbooks. Other names that Romanian readers came into contact with throughout the 1960s are Akutagawa Ryūnosuke, with a translation from English of the short story collection Rashomon, in the rendition of celebrated poet Ion Caraion (1923-1986), Inoue Yasushi and his 1949 Ryojju, translated from German by Lia and Platon Pardău, and even a volume of fragments from Murasaki Shikibu's medieval novel Genji monogatari, translated from English by yet another major name of Romanian literature, female writer Henriette Yvonne Stahl (1900-1984).

It was not until the 1970s and 1980s, however, and the initial relative political recognition of Romania's role as a game-changer within the Soviet bloc and Ceauşescu's acceptance by virtually all major international leaders (he had come to power in 1965, after the death of the first Romanian Communist Party leader, Gheorghe Gheorghiu-Dej), following his refusal to join the Warsaw Treaty military alliance in suppressing the Prague Spring,

1954, writing under the Japanese-sounding pseudonym Onoto Watanna) and her 1902 novel A Japanese Nightingale as "the first translation" from Japanese literature in Romania and "a best-seller." 
that we see a first significant wave of not only political, diplomatic and economic opening toward Japan (Ceauşescu himself visited Tokyo in April 1975 and was received by Emperor Hirohito), but also a cultural and literary opening. Sadly, 1975 also marked Ceauşescu's descent into complete dictatorial mentality and the slow transformation of the communist dictatorship into a nationalist, personality cult-driven regime, led by a tight camarilla surrounding and feeding the dictator's egomaniacal and narcissistic thirst for confirmation and adulation.

The list of titles translated from Japanese literature during the 1970s and $80 \mathrm{~s}$ is too long to mention here, and the critical reception of some of these translations is still difficult to track and outside the scope of the current study. Suffices to say that most of the titles continued to be translated from either English, French, or German (with a smaller number coming from Russian, at least by comparison with the preceding two decades). The first Japanese language major students graduated from the University of Bucharest in 1981, although their numbers remained limited, as the course was only offered once every four years and would remain so until 1993. The interest in Japanese language and culture did pick up and limited number of students were even allowed to study in Japan. The "Ion Dalles" People's University in Bucharest (a lifelong learning alternative to traditional universities) began to offer Japanese language courses in 1982, under the direction of Angela Hondru, who would become the most active and enthusiastic promoter of Japanese culture in Romania, and the most published translator of Japanese literature.

\section{Yukio Mishima in Romanian}

Mishima's first Romanian rendition published in a volume (although it is very possible that short stories, novellas or plays might have been published in cultural and literary magazines of the time) took place in 1979, with his 1960 Utage no ato, translated into Romanian as După banchet (Bucharest: Univers) by one of the first Japanese literature and theatre scholars, Stanca Scholz-Cionca. The 1956 masterpiece novel Kinkakuji was also published in book format, in Angela Hondru's translation, as Templul de aur (lit. "The Golden Temple" and not the "Temple of the Golden Pavilion" as the Japanese name would indicate; Bucharest: Univers). While the two novels could not have gone unnoticed by the literary magazines of the time, at the current stage of this research, it remains 
unclear what their critical/readership reception might have been. It is, however, evident that Japanese literature in general, and modern writers such as Kawabata Yasunari, Mishima Yukio or Abe Kōbō were no longer unfamiliar names to literary critics and readers in Romania. We now begin to find their works mentioned, for instance, in comparative literature research studies, among other works of the time. While still few, the post1990 extraordinary publication "boom" is a clear indication of the fact that Japanese literature translations published prior to the Anti-Dictatorial Revolution of 1989 created just the right appetite for what had long been perceived as an exotic and linguistically unattainable literature and culture.

As it is easily imaginable, the disappearance of the state-mandated censorship apparatus and the liberalization of the publishing industry led to an extraordinary growth of the book market and its impact in Romanian culture after 1990. Books and authors previously forbidden were now free to translate if publishers were able to pay the sometimes-prohibiting copyright costs. And it was most probably copyright and financial difficulties that delayed not only the translation and publication of new Mishima titles in Romania, but also the very necessary republication of the works that had already been translated but were long out of print by the 1990s. As such, the first republication of Hondru's Templul de aur by one of the largest and fastest-growing publishing houses in Romania, Humanitas, occurred only in 2000. Owned and managed by one of the primary leaders of the Romanian intelligentsia, philosopher Gabriel Liiceanu, Humanitas became over the years one of the success stories of Romanian entrepreneurship immediately following the 1989 Revolution. It acquired the rights to translate and publish the entirety of Mishima's literary work, a highly successful enterprise that continues to this day. On the publisher's author page dedicated to Mishima ${ }^{3}$, there are, as of 2021, at least twenty volumes listed, some out of print, some still available, some in two, even three separate editions, and at least one in an audiobook version. Moreover, while other publishers committed to the publication of the critical and historical apparatus necessary to understand the context and environment of various moments in the evolution of Japanese literature - most secondary materials available in English are now available in Romanian as well, including massive endeavours, such as the works of Donald Keene, Katō Shūichi or Yamanouchi Hisaaki-Humanitas continued to focus on primary materials, in this case mainly on Mishima's

3 See https://humanitas.ro/autori/yukio-mishima 
prose. The only secondary source on the Japanese writer ever published by Humanitas was Marguerite Yourcenar's 1980 Mishima, ou la vision du vide, translated as Mishima sau viziunea vidului (2004).

\section{Reception: From Excitement to Scholarship}

In parallel with the translations, Mishima's understanding and critical reception after 2000 has seen a tremendous increase not only quantitively, but also qualitatively. There is without a doubt still a widespread perception of his work as "exotic", as "samurai-like", but currently one may also identify an arguably emotional response from Romanian readers and writers alike, as well as a well-argued and balanced critical understanding of his work.

Here is, for instance, what journalist and writer Andrei Crăciun wrote in 2017, after encountering Mishima's translation of the 1949 Kamen no kokuhaku (translated as Confesiunile unei măşti, by Emil Eugen Pop in 2011):

"I read your book as if in a trance. It's not possible, I told myself, it is simply not possible, for this to be the work of a twenty-four-year-old person. How can it be possible for anyone to write like that at twenty-four?

I have been reading every day for decades. I have never encountered anyone as intimate as you with anguish and with heroism and with death at your age. Or, perhaps, Truman Capote, but not even him... [...]

Your book drove me insane, Mr. Mishima. With all its bloodthirst and all. [...]" (Crăciun 2017)

The academic reception of Yukio Mishima in Romania over the past three decades demonstrates a deeper understanding of the role of his work and contribution to the overall landscape of Japan's postwar literature. Rodica Grigore, a comparative literature scholar from the "Lucian Blaga" University in Sibiu, has written several studies on Mishima's work. In one of her readings of the Japanese author's novel tetralogy, Hōjō no umi (Marea fertilităţii in Romanian) ${ }^{5}$, Grigore rightfully places Mishima within a larger world literary paradigm:

4 Translations from the Romanian are mine, unless specified otherwise.

5 The four novels were translated as follows: Zăpada de primăvară (Haru no yuki, 2009, translated by Angela Hondru); Cai în galop (Honba, 2010, translated by Andreea Sion); Templul zorilor (Akatsuki no tera, 2011, translated by Mihaela Merlan); and Ingerul decăzut (Tennin gosui, 2012, translated by Andreea Sion). 
"Through the vast scaffolding in the Sea of Fertility [...], Mishima orients himself toward the prose of wide breath, without ever intending to somehow abandon the stylistic polishing so characteristic of his earlier work. The model for this endeavor is, at least in part, indebted to Thomas Mann and his Buddenbrooks, from where the Japanese writer borrowed the feel for scenes analyzed in minute detail, and the fascination for the physical side of life always connected with the spiritual side. Mishima, however, distinguishes himself deeply through an unexpected detachment and a narrative perspective that often amaze (while always convincing), but more than anything through surprising acts of courage that represent his ability to separate himself from any model, no matter how prestigious. [...]" (Grigore 2014: 148-149)

Another Romanian researcher, Rodica Frenţiu, a scholar of Japan at "Babeş-Bolyai" University in Cluj-Napoca, focused her research, in a 2013 study, on Mishima's understanding of the samurai code and the ultimate suicide his nationalistic fanaticism led to in 1970 (Frenţiu 2010). While writing in English, Frenţiu also used and cited Romanian translations of Mishima's work, which represents in and of itself the extent to which Romanian scholars of the author have come to rely on resources in their own language over the past two decades.

In addition to prose writings, Mishima's plays have also been translated and staged in Romania. From a 1983 translation of the 1956 Sotoba Komachi in a theatre arts magazine, to the 1951 Seijo and the 1955 Hanjo translated in 2006 as Iubiri interzise (lit. "forbidden love") by Laura Coco$\mathrm{ra}^{6}$, and played for five consecutive seasons (2007-2011) by the Romanian National Theatre, and to acclaimed representations of the 1965 Sado koshaku fujin (Madame de Sade), staged over the years by various Romanian and international troupes all over the country, Mishima's theatre has equally been adopted and adapted by Romanian audiences and connoisseurs alike. Further in-depth research is necessary however to map out the full extent of the adoption and reception of Mishima's theatre by the Romanian audience.

Far from being more than a beginning of a much-needed longer and more thorough research into the reception of Mishima's work in Romania, this research aims to merely open the door on the ways in which a Japanese writer and his work impacted the imagination of his readers from Eastern Europe. And while the translation and reception of his literary works started in Romania perhaps a bit later compared to other European cultures,

6 Hanjo, published in "Luceafărul de dimineaţă", 11-12/2017, p. 27-28; and Seijo, in

"Neuma". 1-2/2018, p. 6-13. 
and definitely late when compared to American culture, Yukio Mishima's acceptance and integration into the cultural and emotional psyche of the Romanian readership is now almost comparable to that of other linguistic and cultural spaces. Perhaps, there is no better way to demonstrate that last assertion than by concluding with a quote from Romanian critic Eugen Uricaru when writing about the father of modern Romanian drama, Ion Luca Caragiale (1852-1912), and his biting humorous criticism of the budding modern Romanian society in the mid-1800s:

“All this enhances Caragiale's mystery and contributes to his monumental presence (within the Romanian letters). [...] It must have been so difficult (for his contemporaries) to bear the truth and the force of his work that ridiculed everything considered to be honourable. Another writer, the Japanese Yukio Mishima, used to say that the only and true wish of someone who has fallen into ridicule is to make all witnesses of that ridicule disappear. Through his way of being, of thinking, and especially of writing, Caragiale was a generator and a witness of the ridicule of a society that was still searching for its new identity." (Uricaru 2012)

\section{BIBLIOGRAPHY:}

BĂICUŞ, Iulian, 2000: Yukio Mishima: Ultimul samurai al scrisului (Yukio Mishima: The Last Writing Samurai), in "Observator cultural", 12 December.

CIAPPARONI LA ROCCA, Teresa (ed.), 2020: Mishima monogatari: Un samurai delle arti (Mishima Monogatari: A Samurai of the Arts), Turin, Edizioni Lindau.

CRĂCIUN, Andrei, 2017: Scrisoare către Yukio Mishima (Letter to Yukio Mishima), in "Ziarul Metropolis", 21 August.

DECIU, Andreea, 2000: Despre frumuseţe şi singurătate (On Beauty and Loneliness), in "România literară", 5 June.

FRENȚIU, Rodica. 2010: Yukio Mishima: Thymos Between Aesthetics and Ideological Fanaticism, in "Journal for the Study of Religions and Ideologies" XIX (25), p. 69-90.

GRIGORE, Rodica, 2017: Proza lui Yukio Mishima. Amintirea trecutului, onoarea prezentului şi adevărul artei (Yukio Mishima's Prose: The Memory of the Past, the Honor of the Present, and Artistic Truth), in "Saeculum" XXXXIV, p. 132-143. 
ANALELE UNIVERSITĂŢII DE VEST DIN TIMIŞOARA. SERIA ŞTIINȚE FILOLOGICE / ANNALS OF THE WEST UNIVERSITY OF TIMIŞOARA. HUMANITIES SERIES

LIX/2021

GRIGORE, Rodica, 2014: Yukio Mishima: Declin, Amurg, Renaştere (Yukio Mishima: Decline, Sunset, Rebirth), in Rodica Grigore, Pretextele textului (The Text's Pretexts), Cluj-Napoca, Editura Casa Cărţii de Ştiinţă, p. 147-156. GRIGORE, Rodica, 2020: Yukio Mishima: Despre moarte şi artă (Yukio Mishima: On Death and Art), in Rodica Grigore, Intre lectură şi interpretare: Eseuri, studii, cronici (Between Reading and Analysis: Essays, Studies, Reviews), Cluj-Napoca, Editura Casa Cărţii de Ştiinţă, p. by, 45-48.

HAŞU-BĂLAN, Mihaela, 2018: Direcții majore în receptarea spiritului nipon în spațiul literar și publicistic românesc în perioada 1920-2010 (Major Directions in the Reception of the Japanese Spirit in the Romanian Literary and Journalistic Space, 1920-2010). Cluj-Napoca, Editura Limes.

JAPAN, Ministry of Foreign Affairs of, 2019: Japan-Romania Relations (Overview). Tokyo, 22 January. https://www.mofa.go.jp/region/europe/romania/ data.html.

MANOLE, Cristina, 2017: Viaţa ca literatură (Life as Literature), in “Observator Cultural", 8 September.

MITRASCA, Marcel, 2006: Japan in Romanian Books before World War Two, in “Acta Slavica Iaponica” XXIII, p. 241-247.

NITOBE, Inazō, 1929: Busido sau Sufletul japonezului (Bushidō, or the Soul of the Japanese), Translated by Constant Georgescu. Bucharest, Editura Casei Şcoalelor.

PURCARU, Alina, 2012: Un om al legii descoperă legea mirajului (A Man of the Law Discovers the Laws of Marvel). "Observator cultural”, 15 June.

RĂSUCEANU, Andreea, 2010: “Cazul” Mishima (Mishima, the "Case"), in "Observator cultural", 18 February.

ŞIPOŞ, George T., 1998: Eros şi Thanatos în Templul de aur (Eros and Thanatos in Mishima's The Temple of the Golden Pavilion), in "Contrapunct”, 25 January, p. 20-21.

TIMUŞ, Ioan, 1924: Japonia: Viaţa şi obiceiurile (Japan: Life and Customs). Bucharest, Editura Casa Şcoalelor.

URICARU, Eugen, 2012: Lovitura de maestru (Stroke of Genius), in "România literară", 10 May.

ZUP, Lucian, 2019: Yukio Mishima şi măşsile eului (Yukio Mishima and the Masks of the Ego), in "Asachiana: Revistă de biblioteconomie şi cercetări interdisciplinare" VII, 11, p. 107-121. 